\title{
APPLICATION OF INVERSE $Q$ FILTERING FOR IMPROVEMENT OF SEISMIC RESOLUTION IN THE ZECHSTEIN FORMATION (SW POLAND)
}

\author{
Monika KRÓL, Kamil CICHOSTĘPSKI, \\ Jerzy DEC \& Kaja PIETSCH
}

\author{
AGH University of Science and Technology, Faculty of Geology, \\ Geophysics and Environmental Protection, Department of Geophysics; \\ al. Mickiewicza 30, 30-059 Krakow, Poland; \\ e-mail: krol@agh.edu.pl,kcichy@agh.edu.pl,.geodec@agh.edu.pl,pietsch@agh.edu.pl
}

\begin{abstract}
Seismic wave attenuation has strong, negative effect on the seismic data resolution. The high influence of this phenomenon was observed during realization of seismic survey "Duża Wólka 3D" (Geofizyka Kraków S.A. 2010a). The resolution of recorded seismic data was very low due to high attenuation caused by the Lower Triassic Buntsandstein sandstones. In consequence, interpretation of the thin-layered Zechstein formation is ambiguous. The aim of this paper is to present the multi-stage algorithm for the purpose of minimizing the attenuation effect, hence increasing the resolution of the seismic data. In order to achieve this, the inverse $Q$ filtering process was used. The $Q$ factor (quality factor) was estimated from the vertical seismic profiling data (Geofizyka Kraków S.A. 2010c). To verify the effectiveness of inverse $Q$ filtering, seismic modelling was performed. Results received from seismic modelling gave basis for application the inverse $Q$ filtering on real data. For this operation the seismic time profile inline 112 was chosen from the seismic data set "Duża Wólka 3D". Application of inverse $Q$ filtering significantly increased the seismic resolution, which enabled the interpretation of the Zechstein formation with more accuracy.
\end{abstract}

Key words: seismic resolution, attenuation, inverse $Q$ filtering, $Q$ factor

\section{INTRODUCTION}

Detailed geological interpretation depends on seismic data resolution. Attenuation of higher seismic frequencies increases with depth. The consequence of this phenomenon is the decrease in seismic resolution (comp. Wang 2008). The high influence of seismic attenuation was 
observed during the acquisition of the seismic survey "Duża Wólka 3D” (Geofizyka Kraków S.A. 2010). This project was carried out in the mining area "Głogów Głęboki Przemysłowy" copper-silver (KGHM S.A.) in Poland. It is located in the southern-central part of the Fore-Sudetic Monocline (Fig. 1). In this region, the Carboniferous basement of the Fore-Sudetic Monocline is covered by the Permian (Rotliegendes and Zechstein) and the Triassic strata (Kłapciński \& Peryt 1996). The aim of the seismic survey "Duża Wólka 3D" was to investigate the thinly layered (from the seismic point of view) structure of the Zechstein formation. The recorded seismic data are characterized by a frequency decline with depth (Dec et al. 2011). One of the possible reasons for this phenomenon can be the high seismic attenuation, caused by the Lower Triassic Buntsandstein sandstones, which rest above the Zechstein formation.

The aim of this paper is to present a multi-stage algorithm for the purpose of minimizing the attenuation effect, hence increasing the resolution of the seismic data in the Zechtstein area. In order to achieve this, the inverse $Q$ filtering process was used, the efficiency of which was tested by the use of seismic modeling.

\section{GEOLOGICAL SETTING}

Within the study area, the Rotliegendes and the Zechstein formations overlay folded Carboniferous formations. The Rotliegendes is developed as brown-red sandstones. The most detailed information about Zechstein in "Głogów Głęboki Przemysłowy” mining area, was provided by the well S-421A. The main objective of this well was to determine the vertical variation of the petrophysical parameters (Geofizyka Kraków S.A. 2010c). Based on the S-421A well-logging, four Zechstein cyclothems were identified. The first, Werra cyclothem is developed as the Copper Shale $(0.8 \mathrm{~m})$, the Zechstein Limestone Ca1 $(10 \mathrm{~m})$, the Lower Werra Anhydrite A1D (85 m), the Oldest Halite Na1 (42 m), and the Upper Werra Anhydrite A1G (48 m). The second - Strassfurt cyclothem is composed of the Main Dolomite Ca2 (18 m) and the Basal Anhydrite A2 (19 m). The third, Leine

cyclothem is developed as the Anhydrite A3 (33 m) and the Grey Salt Clay I3 (2 m). The Aller cyclothem is composed of Brown-red shales I4 (5 m), the Pegmatite Anhydrite A4 ( $3 \mathrm{~m})$ and the Transitional Claystone Ip (14 m). In the "Głogów Głęboki Przemysłowy" mining area the Strassfurt, Leine and Aller cyclothems each are relatively thin, circa $100 \mathrm{me}$ ters in total, while the Werra cyclothem is ca. 180 meters thick. The Mesozoic strata are composed of the Buntsandstein sandstones and the Muschelkalk limestones, which are covered by the Cenozoic sediments with brown coal seam (Kłapciński \& Peryt 1996).

\section{SEISMIC DATA ACQUISITION}

To investigate the geological structure of the study area $\left(1 \mathrm{~km}^{2}\right.$ target area), a 3D seismic survey was acquired by Geofizyka Kraków S.A. (Fig. 1). 


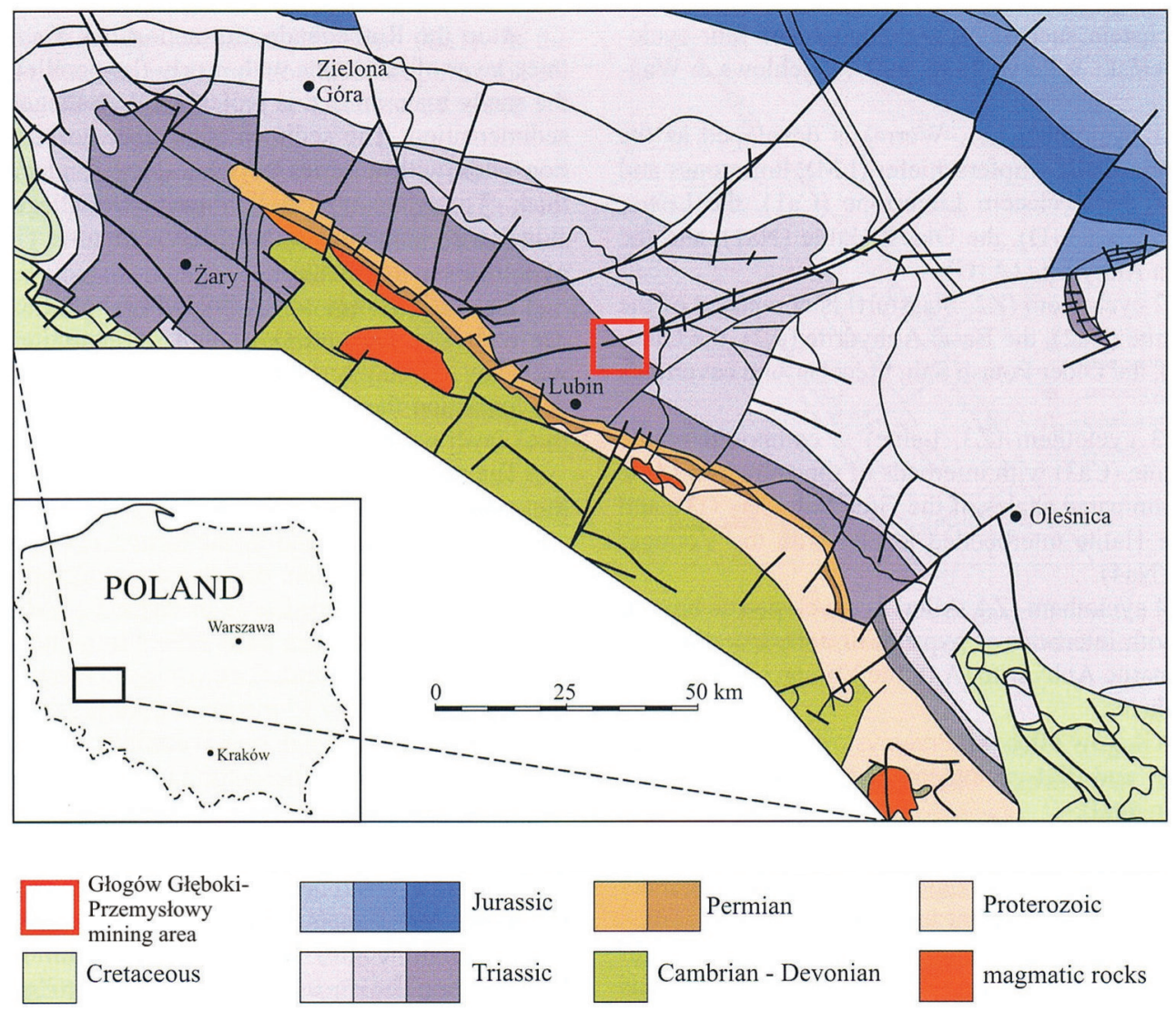

Fig. 1. Geological map of Fore-Sudetic Monocline without Cenozoic strata (Pożaryski 1979)

The horizontal resolution of the seismic data set was $10 \mathrm{~m}(10 \times 10 \mathrm{~m}$ bin size $)$, which was achieved by $20 \mathrm{~m}$ geophone- and shot point spacing. Offset, the main parameter of the 3D survey design, had to be matched to the maximum of the target depth, which in this case was the top of the Rotliegendes at ca. $1200 \mathrm{~m}$. The offset varied between $1236 \mathrm{~m}$ and $156 \mathrm{~m} .8-110 \mathrm{~Hz}, 16 \mathrm{~s}$ long sweeps were generated by two Failing Y-2400 vibrators, during the survey (Geofizyka Kraków S.A. 2010b).

An analysis of the acquired seismic data set Duża Wólka 3D showed that reflections from the top of the Triassic have frequencies about $60 \mathrm{~Hz}$, while the main frequency from the top of the Zechstein drops to $25 \mathrm{~Hz}$. Only interfering reflections from the top Zechstein (Ztop), the oldest halite (Na1), the bottom of the anhydrite (A1D) and some other ones from the top of the Rotliegend formation (P1) are observable in the seismic data set (Fig. 2). 


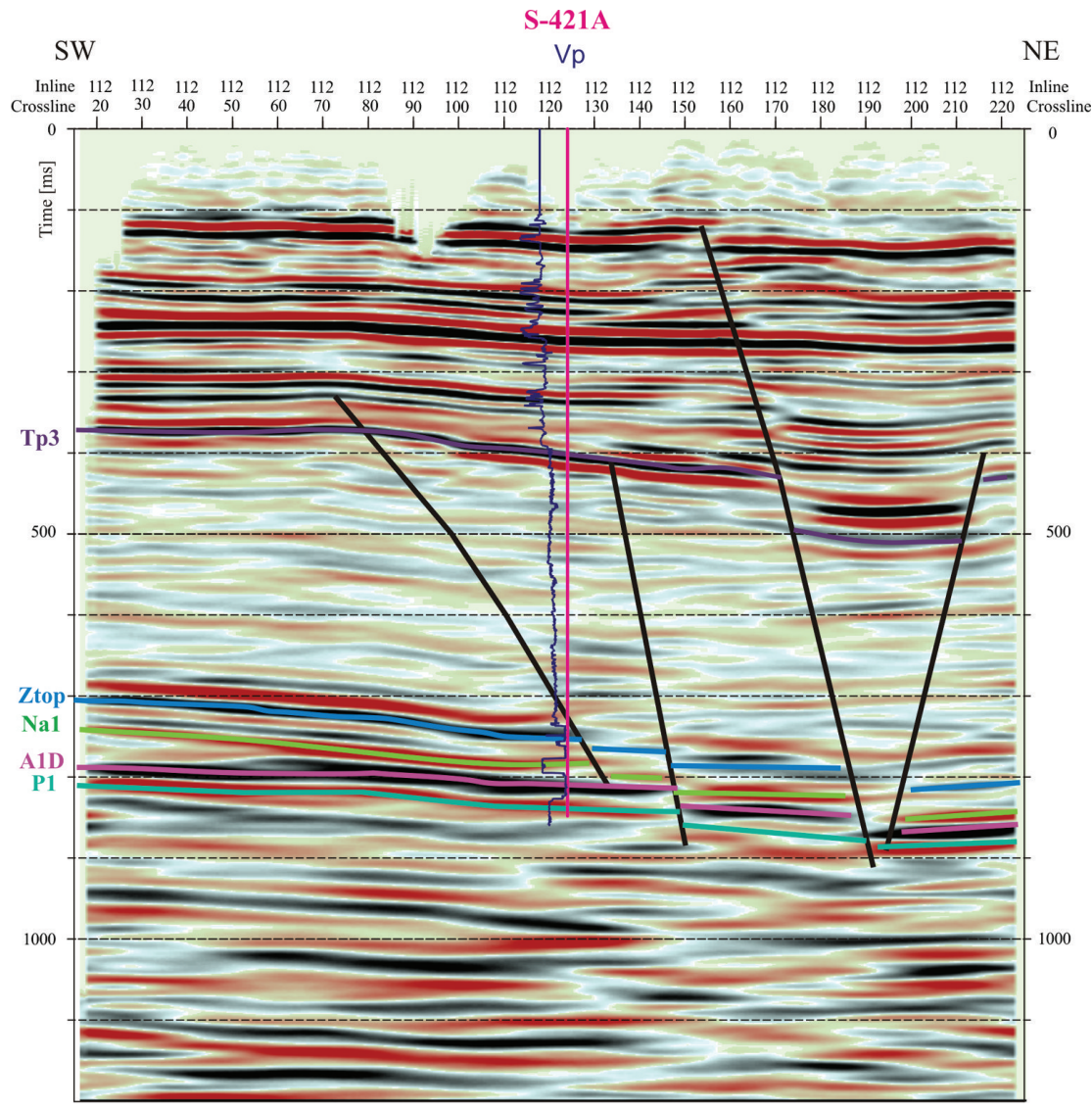

Fig. 2. Seismic time profile inline 112

\section{THEORY}

The measure of seismic attenuation is the $Q$ factor (quality factor). The $Q$ factor is the ratio of fractional energy loss $\Delta W$ per cycle of strain harmonic motion to the maximum energy $W$ stored in the material specimen at the beginning of the cycle, by:

$$
\frac{1}{Q}=\left(\frac{1}{2 \pi}\right) \frac{\Delta W}{W} .
$$

The $Q$ factor is independent of the frequency, whereas the attenuation coefficient $\alpha$, which measures energy absorption, shows the dependency on the frequency $\omega$, by Wang (2008):

$$
\alpha=\left(\frac{\omega}{2 \pi}\right) \frac{1}{Q} .
$$


It can be concluded that the high value of the quality factor $Q$ means small attenuation. The high frequencies are attenuated more than the low ones.

Based on laboratory measurements of P-wave attenuation, the following conclusion can be made (Jarzyna 1999):

- various rocks have their own quality factors $Q$. It has a high value for the limestones and sandstones, smaller for shale and the smallest for the gas saturated sandstones;

- the highest value of $Q$ factor is achieved in perfectly dry rocks, lower in fully saturated rocks and the smallest in the partially saturated rocks;

- quality factor $Q$ can be used to differentiate fluids contained in the rock pores and the lithology.

The influence of the anelastic attenuation on the seismic section can be computed by the Norsar 2D Ray Modelling software (Norsar 2012). The following formula is used for the calculation:

$$
C_{Q}(f)=e^{-\left(\Pi f T_{k}\right) / Q_{k}},
$$

where:

$C_{Q}-$ attenuation coefficient for frequency $f$,

$Q_{k}-$ quality factor in the block corresponding to ray segment no. $k$,

$T_{k}-$ is the travel time for ray segment no. $k$.

This is frequency dependent attenuation formula: "The attenuation is a multiplicative factor in each block (ray segment), and the total attenuation effect along the ray is obtained by the product of $C_{Q}$ 's for all ray segments. In the seismogram generation the total attenuation effect is included by Fourier transforming the seismic signal to the frequency domain, multiplying the spectrum by $C_{Q}(f)$, and transforming the signal back to time. This process will change the frequency content in the signal and consequently we obtain a change in the shape of the signal" (Norsar 2012). Inverse $Q$ filtering is a seismic data processing procedure that compensates for the energy absorption and corrects the wavelet distortion in terms of shape and timing. In consequence, this improves vertical seismic resolution (Wang 2008).

Inverse $Q$ filtering is based on the assumption that the attenuation coefficient is a linear function of the frequency. It is a multistage process in which accurate estimation of $Q$ factor is crucial (Tonn 1989).

In this paper, for $Q$ factor estimation, the authors used the spectral ratio method (Hauge 1981) based on vertical seismic profiling (VSP). Other authors such as Dasgupta \& Clark (1988) describe the method of estimation of $Q$ directly from the surface seismic data. However, it is difficult to provide proper $Q$ values due to the influence of different factors related to data acquisition. Not only Wang (2008) but also Bardi and Mooney (1987), concluded that the $Q$ values of calculated spectral ratio methods are more appropriate than those calculated by other methods. Blias (2011) suggested new method based on optimization approach to $Q$ factor estimation, which is more accurate then spectral ratio method, but it requires further testing. 


\section{METHODOLOGY}

The spectral ratio method is applied most often for $Q$ factor estimation, based on zero-offset vertical seismic profiling data (Blias 2011). It was accomplished on the S-421A well data. The quality factor $Q$ was estimated by determining the trend of the cumulative attenuation curve as a function of depth (Fig. 3).

The estimation of the $Q$ factor was carried out by the Vista 2D/3D Seismic Processing software (Gedco 2012). Selection of the proper parameters for $Q$ factor estimation is crucial. After verification, the most optimal parameters were chosen: time windows of 80-200 ms and frequency of 20-80 Hz. The shape of the cumulative attenuation curve highly depends on the time window and the frequency range. At the second stage the seismic modelling was performed (Norsar 2012). The aim of this was to verify the effectiveness of the inverse $Q$ filtering in the investigated area. At the last stage, the inverse $Q$ filtering was performed on the real data set (Gedco 2012).

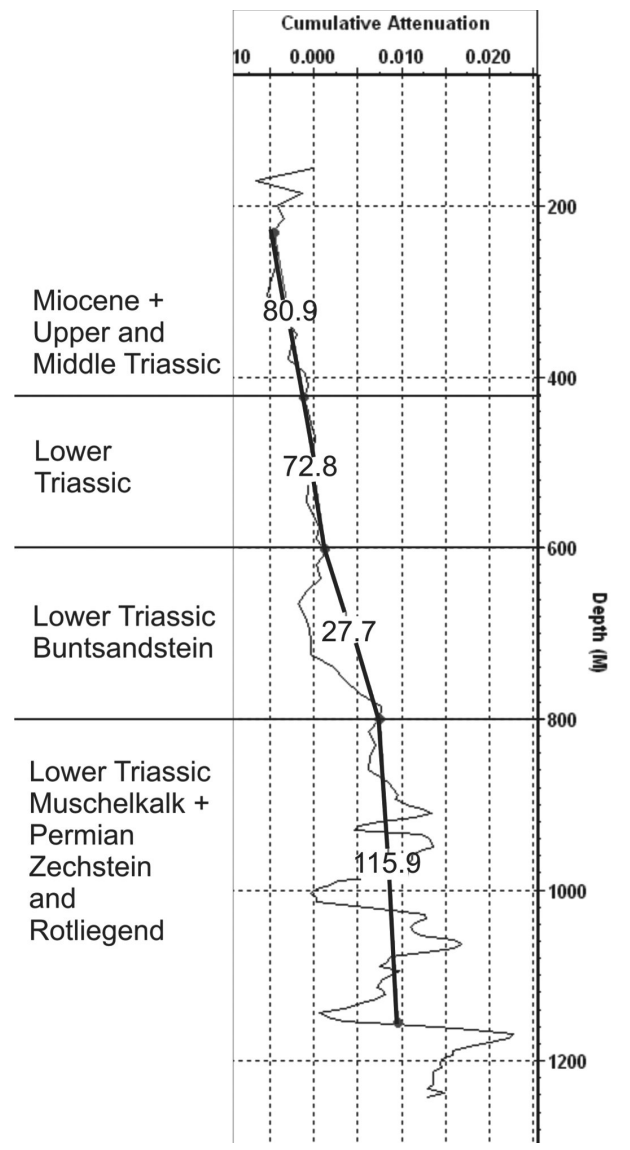

Fig. 3. Cumulative attenuation curve with estimated $Q$ factors 


\section{SEISMIC MODELLING}

The aim of seismic modelling (Fig. 4) was to answer the question whether the inverse filtering increases the frequencies, hence improves the data resolution. The seismic $2 \mathrm{D}$ models were created based on interpreted inline 112 (Fig. 2), the well log data from S-421A and the estimated $Q$ factor values. Seismic modelling was performed in Norsar 2D Ray Modelling software (Norsar 2012) using zero-phase Ricker wavelet of dominant frequency $60 \mathrm{~Hz}$, what was simulating frequency observed on Triassic top. Seismic modelling was made using the option Normal Incidence Paths (NIP Ray Tracer).

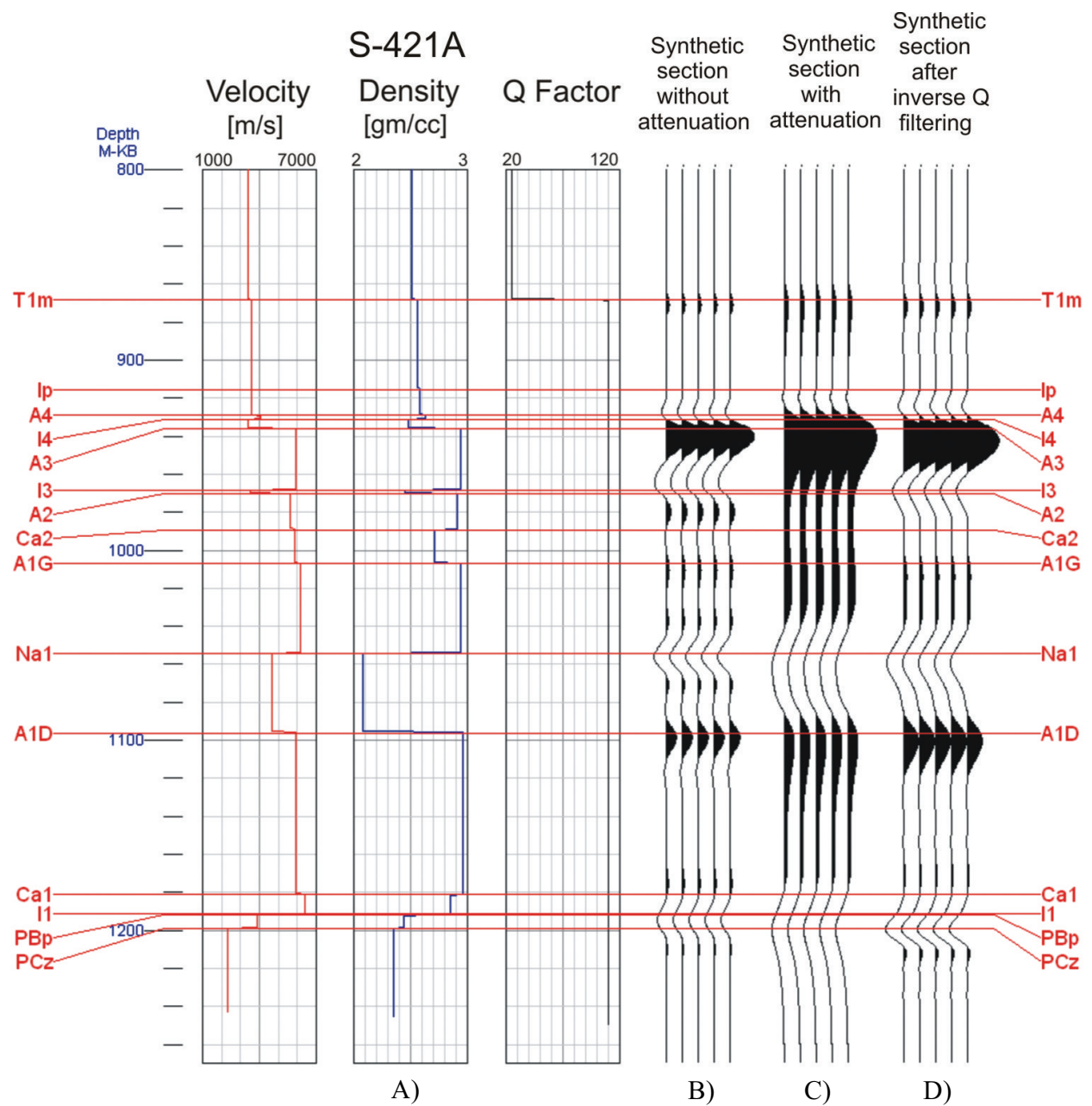

Fig. 4. Velocity, density, quality factor $Q$ (A). Synthetic section computed for model without attenuation (B). Synthetic section computed for model with attenuation (C).

Result of applying inverse $Q$ filtering on synthetic section with attenuation (D) 
Figure 4 shows the time window of seismic modeling for the Zechstein formation: A) velocity, density, quality factor $Q$; B) synthetic section computed for the model without attenuation; C) synthetic section computed for the model with attenuation; D) result of applying inverse $Q$ filtering on synthetic section with attenuation. Comparison of synthetic seismograms (Fig. 4B-D) with petrophysical model (Fig. 4A) shows that it is impossible to distinguish all thin layers in the Zechstein formation. On the synthetic seismic section for model with attenuation (Fig. 4C) there is a clear decrease of frequency with depth. The synthetic section after the inverse $Q$ filtering shows that the frequencies at the Zechstein formation are distinctly higher (Fig. 4D). Moreover, the inverse $Q$ filtering corrects the wavelet (Fig. 5). After inverse $Q$ filtering, the width of the wavelet has been decreased, the obtained waveform is closer to assumed (cross correlation 0.77). Consequently, the vertical resolution increases and separation of the reflections from the Upper Werra Anhydrite (A1G), the Lower Anhydrite (A1D), the Oldest Halite (Na1) and the Zechstein Limestone $(\mathrm{Ca} 1)$ is possible.

A)

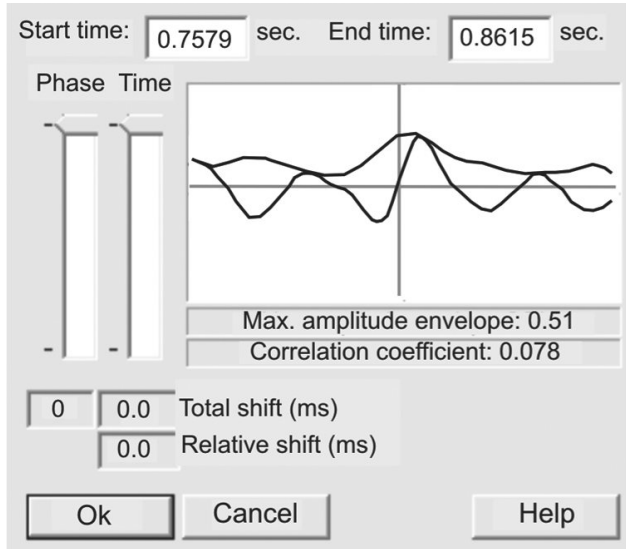

B)

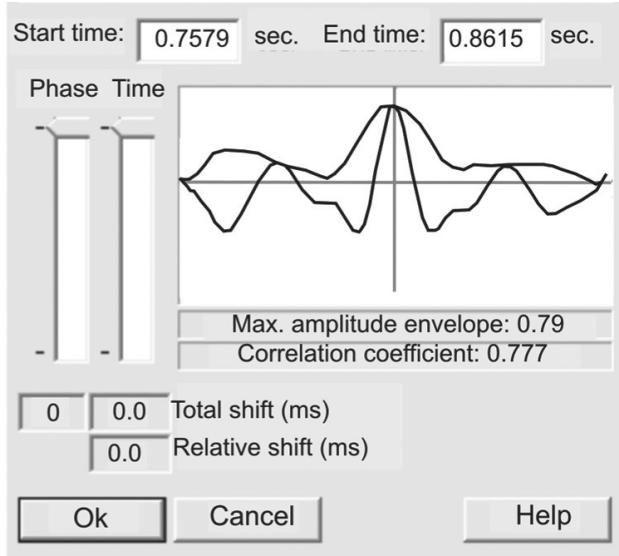

Fig. 5. Cross correlation graphs between: A) synthetic section without attenuation and synthetic section with attenuation; B) synthetic section without attenuation and synthetic section with attenuation after inverse $Q$ filtering

\section{REAL DATA EXAMPLE}

The results received from seismic modeling gave basis for the application the inverse $Q$ filtering on real data. From the project "Duża Wólka 3D", seismic profile inline 112 was chosen (Fig. 2) as the closest to the wellbore S-421A. This seismic section was processed with the application of the inverse $Q$ filtering before stacking. Similarly to seismic modelling, the effectiveness of the inverse $Q$ filtering is demonstrated by comparing the synthetic 
seismogram, the recorded seismic section and the section after the inverse $Q$ filtering (Fig. 6). Synthetic seismic section was calculated by GeoGraphix Discovery software (LKMR 2012). Synthetic seismograms were computed using velocity and density logs from borehole S-421A, as well as statistically extracted wavelet from the seismic data. Figure 6 shows: A) velocity and density logs obtained from well S-421A; B) fragment of the seismic section of the Zechstein formation before $Q$ inverse; C) fragment of seismic section of the Zechstein formation after the inverse $Q$ processing.

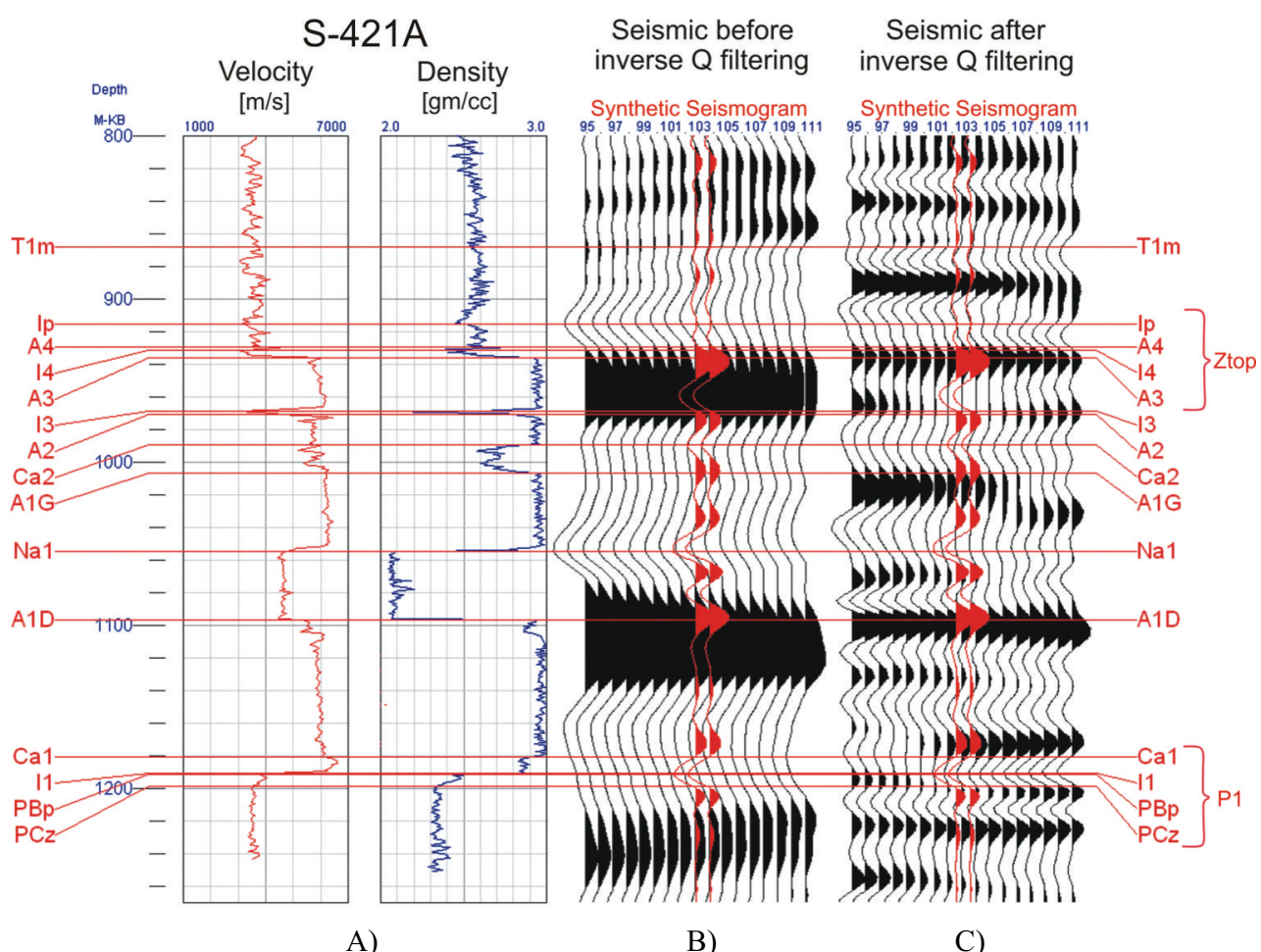

Fig. 6. Velocity and density $\operatorname{logs}$ from well S-421A (A). Fragment of seismic section for the Zechstein formation before inverse $Q$ filtering (B). Fragment of seismic section for the Zechstein formation after inverse $Q$ filtering (C)

\section{RESULTS}

As it can be observed in Figure 6, application of the inverse $Q$ filtering on inline 112 shows a significant increase in the frequency content of the signal and therefore increase of the seismic resolution of the data. 
As a result of application of this procedure it is possible to distinguish the following Zechstein layers: Ztop - interfered signal contains reflection form the Transitional Claystone (Ip), the Pegmatite Anhydrite (A4), the Brown-red Shale (I4) and the Main Anhydrite (A3); positive reflection form the Basal Anhydrite (A2); negative reflection form the Main Dolomite (Ca2); negative reflection form the Oldest Halite (Na1); positive reflection form the Lower Anhydrite (A1D); P1 - interfered negative signal contains reflections from the Zechstein Limestone (Ca1), the Copper Shale (I1), the Weissliegend (PBp) and the top of the Rotliegend (PCz).

\section{DISCUSSION}

Because of the low resolution of the acquired seismic data, Dec et al. (2011) distinguished only three interfered reflections within the Zechstein formation. As it is observed on Figure 6B, they are represented only by two positive and one negative events. The first of them was interpreted as the Zechstein top (Ztop), which contains signal from the Transitional Claystone (Ip), the Pegmatite Anhydrite (A4), the Brown-red Shale (I4) and the Main Anhydrite (A3). The second positive reflection is from the Lower Anhydrite (A1D). The negative reflection corresponds to the Oldest Halite (Na1). Application of inverse $Q$ filtering enhanced the vertical resolution, therefore reflections from other Zechstein layers could be identified. Additionally, there are some events observed from: the Basal Anhydrite A2, Main Dolomite Ca2, the Upper Werra Anhydrite A1G and the Zechstein Limestone Ca1. Therefore, identification of seismic horizons may become more accurate. In the light of the obtained results, the authors recommend reprocessing of the seismic data set with the application of inverse $Q$ filtering and then reinterpretation of the 3D Land Seismic "Duża Wólka" survey.

\section{CONCLUSION}

The presented results demonstrate the usefulness of the inverse $Q$ filtering as a tool for improving the resolution of the seismic data set. Some general and significant conclusions are worthy of note:

- inverse $Q$ filtering increases the dominant signal frequencies which results in enhancing of the vertical resolution,

- after application of inverse $Q$ filtering, interpretation of the Zechstein formation can be done with better accuracy.

Additional reflections corresponded to: the Basal Anhydrite A2, Main Dolomite Ca2, the Upper Werra Anhydrite A1G, and the Zechstein Lime-stone Ca1 can be distinguished. What is even more important, reflection from the bottom of the Rotliegend (P1) can be recognised. 


\section{REFERENCES}

Bardi M. \& Mooney H.M., 1987. Q measurements from compressional seismic waves in unconsolidated sediments. Geophysics, 52, 772-784.

Blias E., 2011. Optimization Approach to Q-factor Estimate from VSP Data. $73^{\text {rd }} E A G E$ Conference \& Exhibition incorporating SPE EUROPEC 2011, Vienna, 23-26 May 2011.

Dasgupta R. \& Clark R., 1998. Estimation of Q from surface seismic reflection data. Geophysics, 63, 288-290.

Dec J., Pietsch K. \& Marzec P., 2011. Application of seismic methods to identify potential gas concentration zones at the Zechstein Limstone level in the "Rudna" mining area, SW Poland. Annales Societatis Geologorum Poloniae, 81, 63-78.

Geofizyka Kraków S.A., 2010a. Dokumentacja wyników badań sejsmicznych, temat Sejsmiczne badania powierzchniowe Duża Wólka 3D. Archiwum KGHM Polska Miedź S.A. [unpublished report].

Geofizyka Kraków S.A., 2010b. Sprawozdanie końcowe z prac polowych, temat - Duża Wólka 3D. Archiwum KGHM Polska Miedź S.A. [unpublished report].

Geofizyka Kraków S.A., 2010c. Opracowanie wyników badań sejsmiki otworowej $S$-421A. Archiwum KGHM Polska Miedź S.A. [unpublished report].

GeoGraphix Discovery Manual, 2009. LMKR, Dubai.

Hauge P.S., Measurements of attenuation from vertical seismic profiles. Geophysics, 62, 1548-1558.

Jarzyna J., 1999. Determination of attenuation of elastic waves in rock medium from interpretation of acoustic full wavetrains. Geofizyka w Geologii, Górnictwie i Ochronie Środowiska: V Konferencja Naukowo-Techniczna Jubileusz 50-lecia Nauczania Geofizyki w Akademii Górniczo-Hutniczej, Kraków 23 czerwca 1999, Akademia Górniczo-Hutnicza, Wydział Geologii, Geofizyki i Ochrony Środowiska, Zakład Geofizyki, Kraków.

Kłapciński J. \& Peryt T.M., 1996. Budowa geologiczna Monokliny Przedsudeckiej. [in:] Piestrzyński A. (ed.), Monografia KGHM Polska Miedź S.A., Lublin, 69-77.

Norsar 2D Ray Modelling Manual, 2012. Norsar, Kjeller.

Pożaryski W., 1979. Mapa geologiczna Polski i krajów ościennych 1:000 000. Wydawnictwa Geologiczne, Warszawa.

Tonn R., 1989. Comparison of seven methods for computation of Q. Physics of the Earth and Planetary Interiors, 55, 259-268.

Wang Y., 2008. Seismic Inverse Q Filtering. Blackwell Publishing, Oxford.

Vista 2D/3D Seismic Processing 12 Manual, 2012. Gedco, Calgary. 
